\title{
The Estimation of the Energy Demand in Yemen: An Econometric Model Approach 1990-2012
}

\author{
Abdulkarim Ali Dahan ${ }^{1}$ \\ ${ }^{1}$ Faculty of Business, Ajman University of Science \& Technology, Ajman, UAE \\ Correspondence: Abdulkarim Ali Dahan, Faculty of Business, Ajman University of Science \& Technology, Ajman, \\ UAE. E-mail: a.dahan@ajman.ac.ae
}

Received: September 16, 2013

Accepted: November 29, $2013 \quad$ Online Published: January 23, 2014

doi:10.5539/ijef.v6n2p125

URL: http://dx.doi.org/10.5539/ijef.v6n2p125

\begin{abstract}
The purpose of this research is to analyze the relationship between energy consumption and economic growth in Yemen during the period 1990-2012. It will also assess the impacts of changes in energy prices on aggregate energy consumption, and conclude with analyzing the relationship between efficiency (oil intensity of use) and total energy consumption during the same period. We used time series data to provide estimates of elasticities. Empirical results showed: (1) The impact of income on energy consumption is positive and was represented by the high elasticity. (2) The price-index has no significant effect on restraining total energy demand. (3) A significant effect of efficiency on energy consumption indicated by the high elasticity reported. This research concludes that both income and efficiency variables have significant impacts as expected on the demand for energy consumption in Yemen. As these two factors increase over time, energy consumption will increase and be more efficient for use which is consistent with the goals of economic growth and the sustainability of development in the future. The price, on the other hand, has no significant effect on restraining the demand for energy. Low energy prices will always increase its demand and bring into more inefficient use of energy. This implies that actions are essential for more sustainable development without adverse effects on national growth targets.
\end{abstract}

Keywords: energy economics, modeling, estimation, policy

\section{Introduction}

Since the beginning of the nineties, Yemen has gone through significant structural changes in its economy. These changes have included rapid increases in the demand for energy use domestically which have increased from 76,000 barrel per day in 1990 to 177,000 barrel per day in 2012, growing at an annual average rate of $29.7 \%$. Factors such as rising incomes, population growth, and cheap energy prices were the main sources for such increases.

Petroleum product prices which do not reflect the real cost of production remained low comparing to international standards. These low prices permitted such inefficient use of energy and gave no such incentives for consumers to conserve energy.

Since the economic reform program, initiated in the mid 90s, the government of Yemen has taken measures and policies to reduce this inefficient use in energy consumption. Its last measures were taken in 2005 and 2011 when prices of energy went up by approximately 60-80 percent.

What motivated me to do this study is the lack of published studies in Yemen that analyzes energy consumption and investigates its determinants analytically. It was that realization which prompted this study of energy demand and the development of behavioral equation consistent with economic theory which provides information concerning the energy consumption and the behavior of consumers in Yemen.

Earlier in this study, it became clear that a comprehensive model of Yemen energy consumption could not be constructed and estimated because of the lack of data on important determinants. Consequently, when model could be estimated, it is by necessity simple. Modeling in this study is not an end of itself; rather it is justified only to the extent that it facilitates the identifications of future consumption possibilities and useful energy policies.

The following sections addresses briefly the objectives, methodology and hypothesis of the study. Energy overview in Yemen will be discussed and analyzed in section four. The fifth section highlights the model and its estimation; and finally, Summary of research findings and conclusions are presented and discussed in section six. 


\section{The Objectives of the Study}

1) To analyze the overall performance of the oil sector in Yemen economically.

2) To build an econometric model for the oil consumption in Yemen that can be used for estimation and future use.

3) To test and evaluate the impact of economic determinants such as income, price, and efficiency on energy consumption during the past twenty years.

4) To recommend effective energy policy that can reduce the inefficient use of energy resources without adverse effects on national growth targets.

\section{Methodology and Hypothesis of the Study}

The design of this research is basically quantitative. It studies and analyzes the relationship between energy consumption and economic factors such as economic growth and energy prices. Rapid economic growth in LDC's generally contributes to large increase in energy demand, (Pindyk, 1979). Prices of gasoline or diesel will be used in our analysis, but if insignificants were found, consumer price index will be used as a proxy instead. This research will also assess the relationship between efficiency (oil intensity of use) and total energy consumption during the same period. High energy intensities indicate a high price or cost of converting energy into GDP, while low energy intensity indicates a lower price or cost of converting energy into GDP, (Chefurka, 2007). Time series data which have been collected from different sources such as the government of Yemen, the World Bank, and the Energy Information Administration will be used to provide estimates of elasticities .

To test the hypothesis, economic determinants chosen in this study will have significant impact on energy consumption, and an econometric model will be used. Firstly, the methodology of the study will analyze the oil production, the oil consumption, and their prices in Yemen economically. Secondly, the methodology will estimate the total demand for energy consumption during the period 1990-2012. The estimations will include gross domestic products, energy prices, and efficiency.

\section{Energy Overview in Yemen}

\subsection{Oil Production}

Unlike many regional oil producers, Yemen relies heavily on foreign oil companies that have production-sharing agreements with the government. The agreements between the government of Yemen and the producing companies dictate that on average, $58 \%$ of the total production is for government share, whereas $42 \%$ for companies shares. About $63 \%$ of government's share goes for export, whereas $37 \%$ goes for domestic use.

Oil production which started in 1986, has increased from 192,000 barrels per day in 1990 to 441,000 barrels per day in 2001, and reached its peak growing at an annual rate of $28.5 \%$. After 2001, oil production from the existing fields have gone through dramatic declines reaching 154,000 barrels per day in 2012, Figure 1.

According to statistics published by the Energy Information Administration, if no new discoveries are found, the existing reserves are not expected to last more than 10 years, and the output from the country's previous fields is falling.

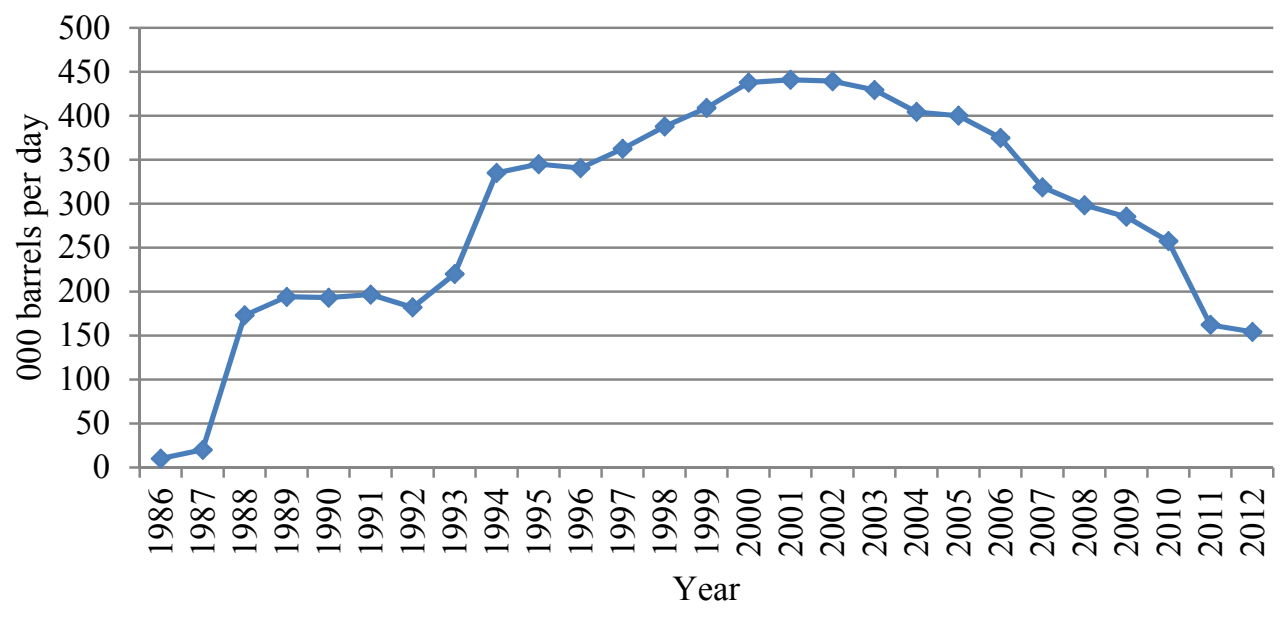

Figure 1. Oil production in Yemen (000 barrel per day) 


\subsection{Refining Sector}

Yemen has two oil refineries with a total capacity of 180,000 barrels per day. Aden refinery came on stream in 1954 with total capacity of 170,000, and Marib refinery came on stream in 1986 with total capacity of 10,000 barrels per day. Both refineries produce a wide array of petroleum products, including heating oil, gasoline, diesel and LPG.

During the last twenty years, refinery capacity from the two refineries increased from 115,000 barrels per day in 1992 to 140,000 barrels per day in 2012, steadily increasing at an average annual rate of 1\%, Figure 2.

Aden's refined products are for domestic use and contracted deals especially with Iran, Oman and Malaysia, while Marib's products are planned for the domestic use only.

Since May 2011, both refineries have been shut several times due to continuing attacks on connecting crude pipelines, causing products shortages in local markets, and making Yemen reliant on crude and products imports mainly from neighboring Saudi Arabia.

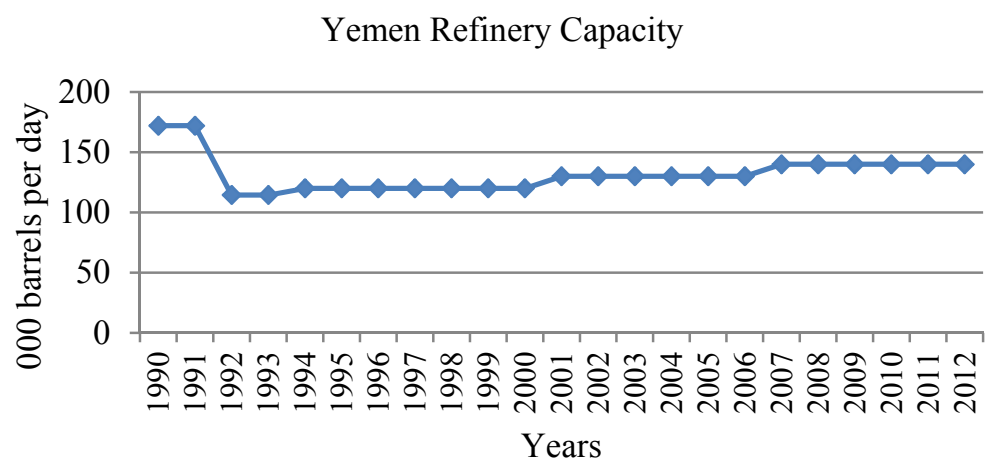

Figure 2. Refinery product ( 000 barrels per day)

\subsection{Crude Oil Consumption}

Many different types of petroleum products have been used in different areas. Products such as gasoline, diesel, kerosene, LPG and residual fuels are the dominant commercial energy products in the country.

Crude oil is refined to produce a wide array of petroleum products. This includes heating oil, gasoline, diesel and jet fuels; lubricants; asphalt; ethane, propane, butane; and many other products used for their energy or chemical content. In the last twenty years, the total crude oil consumption has gradually increased from 76,000 barrels per day in 1990 to 177,000 barrels per day in 2012 growing at an annual average rate of $29.7 \%$, Figure 3.

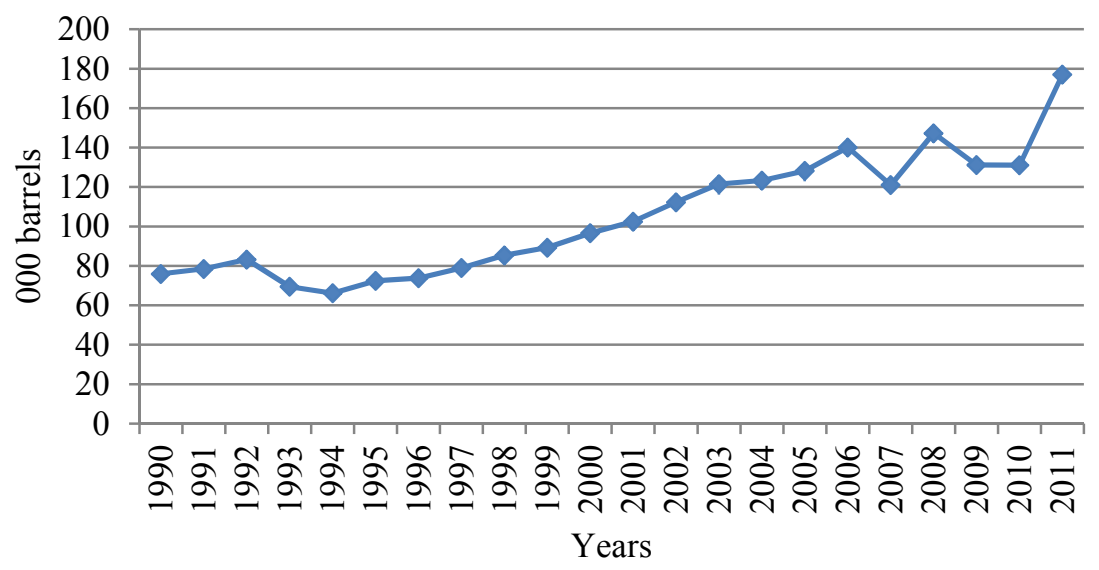

Figure 3. Total oil consumption in Yemen (000 barrels per day) 


\subsection{Price Structure of Petroleum Products}

Pricing of petroleum products in Yemen are not determined by the market. Instead, it is set by the government of Yemen. The prices of these products are subsidies by the government and are low comparing to international standard. This does not only cause fiscal burden on the government, but also drive the demand higher.

In conclusion, petroleum prices in Yemen are under priced in relation to any rational base of comparison, such as the true national economic cost of energy production, marginal costs and prices. The resulting prices fail to reflect relative scarcities or assures supply and demand balance.

To measure the effect of oil prices on energy consumption, prices of gasoline and diesel will be included in our analysis. Although prices of energy in Yemen have been increased several times during the study period, prices were mostly relatively constant. Thus, it might have no significant effect on restraining total energy demand, Figure 4.

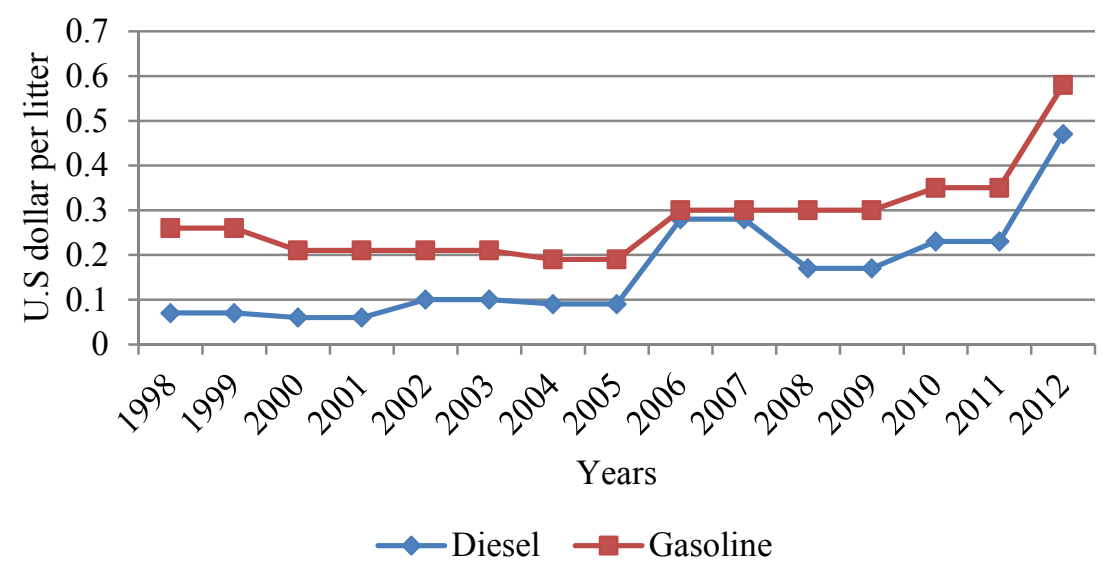

Figure 4. Retail oil prices in Yemen (US dollar per litter)

If the prices of gasoline and diesel were found insignificant, consumer price index will be used as a proxy instead. In the last twenty years, the consumer price index has gradually increased growing at an average annual rate of $16.8 \%$, Figure 5 .

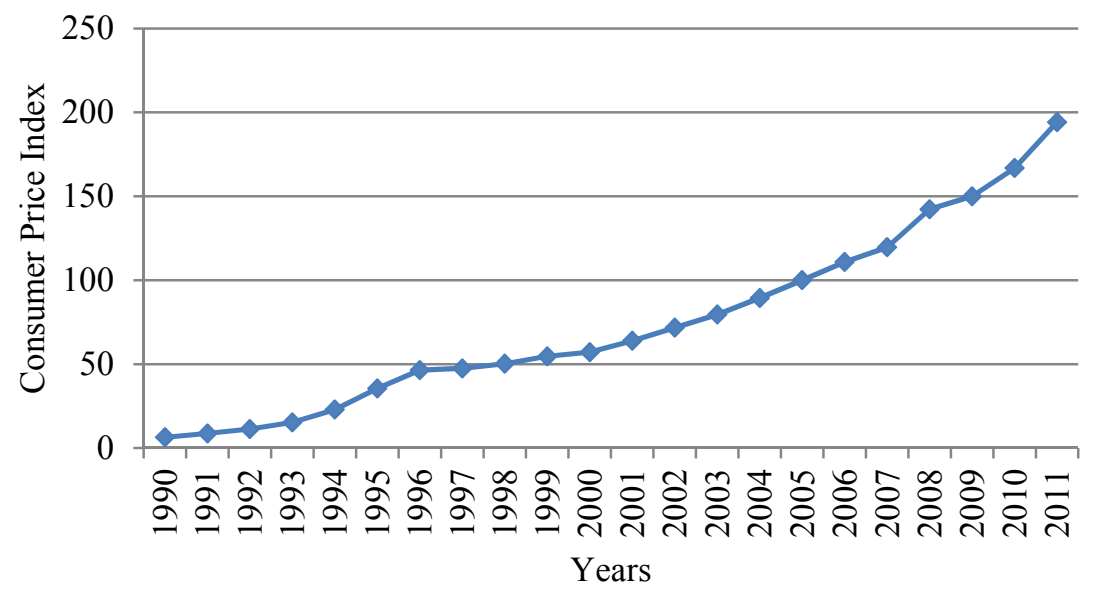

Figure 5. Consumer price index $(2005=100)$ 


\subsection{Economic Growth}

Yemen is a low income country that is highly dependent on declining oil resources for revenue. Petroleum accounts for roughly $25 \%$ of GDP and $70 \%$ of government revenue. Yemen has tried to counter the effects of its declining oil resources by diversifying its economy through an economic reform program initiated in 2006 that is designed to bolster non-oil sectors of the economy and foreign investment.

In the last twenty years, constant GDP per capita gradually increased from $\$ 465$ in 1990 to $\$ 609$ in 2010, growing at an average annual rate of $1 \%$, Figure 6.

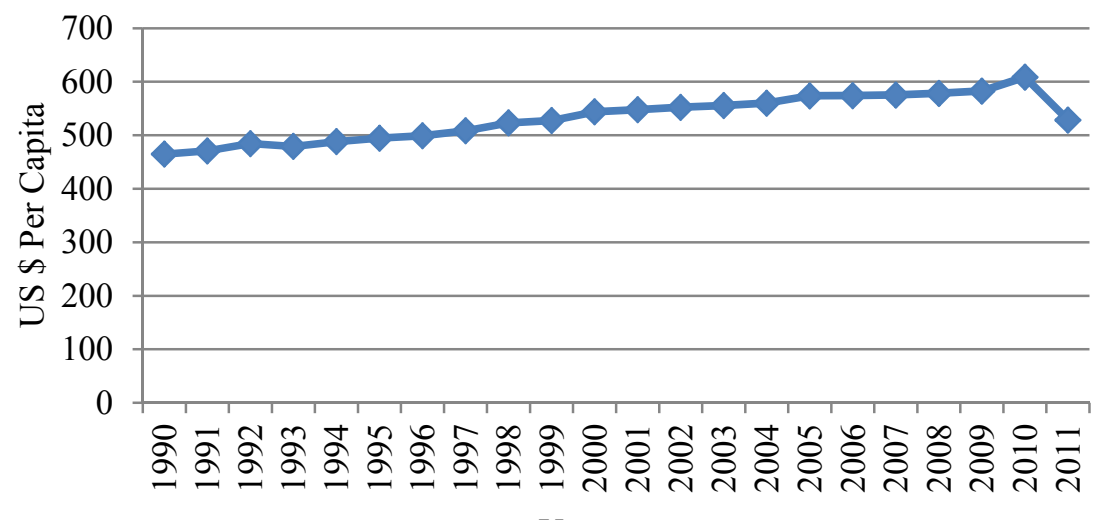

Years

Figure 6. Constant GDP per capita in US. dollar

\subsection{Energy Efficiency}

Energy efficiency is the amount of energy it takes to produce a dollar's worth of economic output. It is called energy intensity of use. This measures energy efficiency of a nation's economy. It is calculated as units of energy per unit of Gross Domestic Product (GDP). This value varies widely between countries depending on their level of industrialization, the mix of services, manufacturing in their economies and the attention they pay to energy efficiency.

In Yemen, the energy intensity of use (efficiency) has fluctuated from year to year. Over the past 20 years, this indicator reached a maximum value of 8.82 in 2010 and a minimum value of 5.62 in 1991, Figure 7.

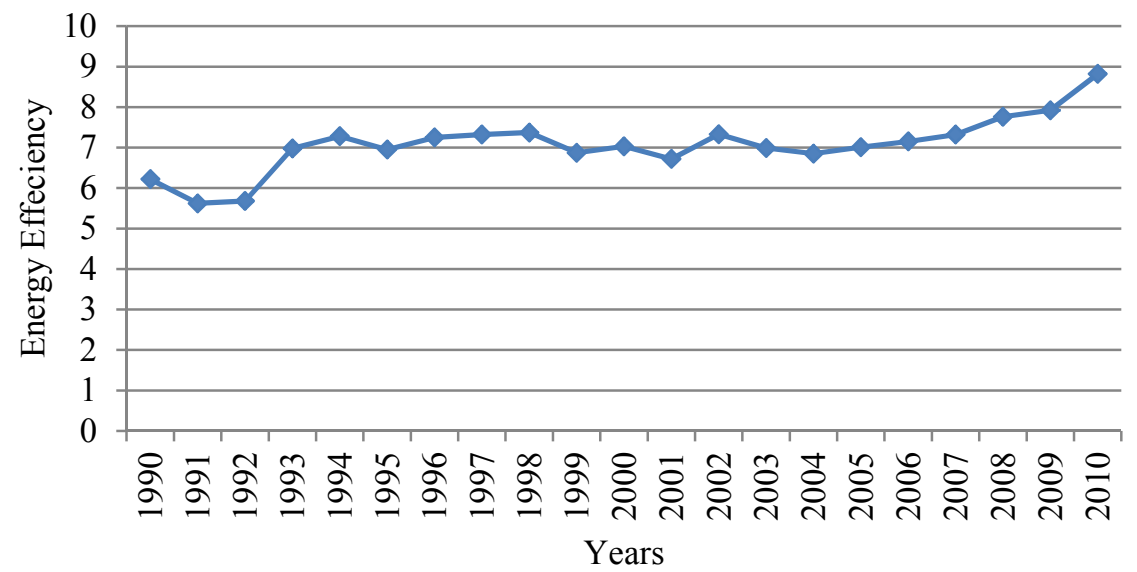

Figure 7. Energy intensity of use 


\section{Model Form}

Simple log-linear model with a koyck lag to explain the dynamic adjustment of demand to changes in income, price and efficiency will be estimated in the form:

$$
\text { In } \boldsymbol{Q} t=A+B \text { In } \mathbf{Y} t+C \operatorname{In} \boldsymbol{P} t+D \text { In E } t+F \text { In } Q t-1+\boldsymbol{e t}
$$

Where:

$\boldsymbol{Q} t=$ Quantity of oil consumed (crude oil);

$\boldsymbol{Y} t=$ Constant GDP per capita;

$\boldsymbol{P} t=$ Price of oil (consumer price-index);

$\boldsymbol{E} t=$ Efficiency (intensity of use);

$\boldsymbol{Q} t-1=$ Lag one year;

$\boldsymbol{e} t=$ Error term.

When this model is not appropriate, or the stock adjustment term is not statistically significant, a simple linear model will be used instead.

Retail prices of gasoline and diesel per liter will be used in our analysis, but if insignificants are found, consumer price index will be used as a proxy instead.

\subsection{Elasticity Estimations}

The elasticities reported will be considered as general indicators rather than the exact estimates since they are based on a crude and simple model of demand along with a price index.

\subsection{Model Estimation}

Simple log log model was found to best fit the oil consumption data. The initial estimate of the equation shows that all coefficients are well determined at the 5\% level of significant except for the lag term in the demand which was found to be insignificant. Thus, the equation was re-estimated with the lag suppressed giving the following equation:

$$
\log Q t=-12.16+3.13 \log Y t-0.21 \log P t-0.62 \log E t
$$

$$
\begin{array}{llll}
(-3.5) \quad(5.6) \quad(-3.7) \quad(-2.7)
\end{array}
$$

$\mathrm{R}^{2}=0.71, \mathrm{D}-\mathrm{W}=2.1,(1990-2010)$.

This equation shows the result of procedures to correct for autocorrelation. The actual and fitted data are shown in Figure 8 .

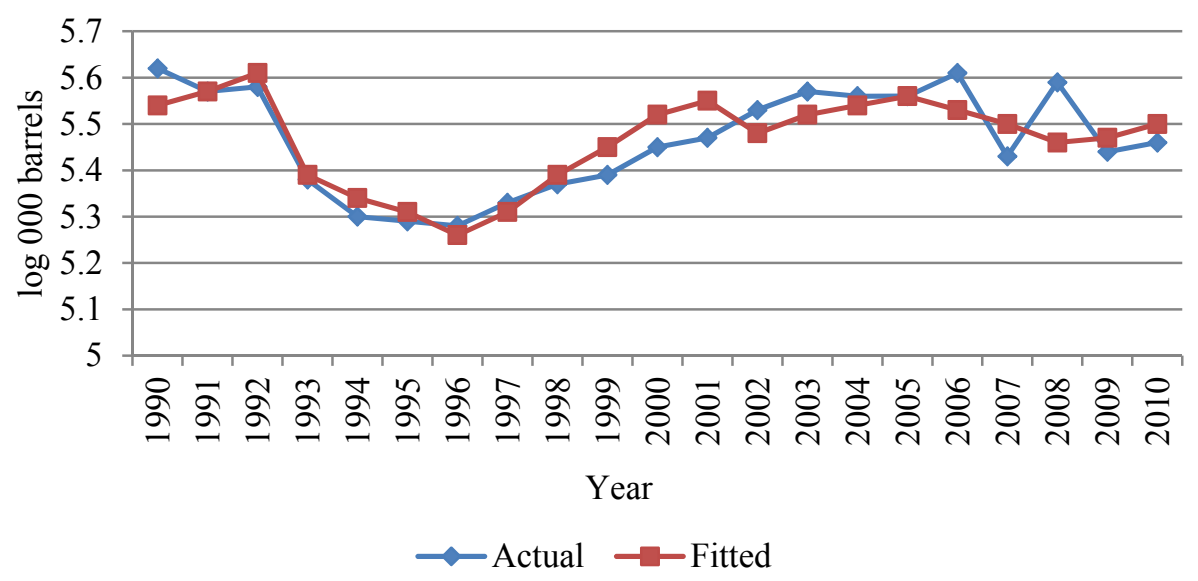

Figure 8. Actual and fitted oil consumption

\section{Research Findings}

The estimated equation shows that about $71 \%$ of the variation in the demand for energy is explained by income, 
price and efficiency. The impact of income on energy consumption is indicated by the high income elasticity of (1.96), which is evaluated at the mean of GDPs. This value implies that as income increases by $1 \%$, energy consumption is increased by $1.96 \%$.

In an attempt to see the effect of oil prices on energy consumption, retail prices of gasoline and diesel were included in the estimated equations, but none of them were significant, therefore they were omitted from the analysis. On the other hand, the estimated equation was re-estimated using the consumer price index which showed some impact on energy consumption indicated by the elasticity of $(-0.28)$ indicating that as price increases by $1 \%$, energy consumption will decrease by $0.28 \%$.

Finally, the result shows a significant effect of efficiency on energy consumption which is indicated by the high elasticity of $(-1.5)$. This indicates that as efficiency increases by $1 \%$, the demand for energy consumption will decrease by $1.5 \%$.

Although the values of R2 are not high, the value of the D-W statistic is quite high and all values are significant at the $5 \%$ level of significance with $t$-values in parentheses. This result indicates that besides the gross domestic product, price and efficiency there are some other factors that affect the demand for commercial energy in Yemen. Thus, the result above is measuring only the relationship between these three factors and commercial energy consumption while the effects of other factors are omitted from the equation. The preferred solution to the low R2 problem is to search for the missing variables and include them in the model.

This research concludes that both income and efficiency variables have significant impact as expected on the demand for energy consumption in Yemen. As these two factors increase over time, energy consumption will increase and be more efficient (meaning it uses less energy to perform the same task as before), which is consistent with the goals of economic growth and sustainability of development in the future. The price on the other hand, has no significant effect on restraining the demand for energy. Low energy prices will always increase its demand and bring into more inefficient use of energy. This implies that actions by the government are essential for more sustainable development without adverse effects on national growth targets.

\section{References}

ATS. (2004). The Worlds Energy Supply. Past, Present, and Future. Retrieved from http://www.abovetopsecret.com/forum/thread61253/pg1

Bukhari, M. S., Sillah, H., \& Al-Sheikh, M. H. (2012). Income, price, and government expenditure elasticities of oil in the gulf cooperation council countries. International Journal of Energy Economics and Policy, 2(4), $333-341$.

Burright, B. K., \& Enns, J. (1974). Econometric models of demand for motor fuel. Rand, R-1561-NSF, Santa Monica, Calif.

Chefurka, P. (2007). Energy Intensity and GDP in 2050. Retrieved from http://www.paulchefurka.ca/WEAP2/Energy_Intensity_GDP_2050.html

CIA World Fact book. (2011, January). Determinants of energy intensity: A preliminary investigation of Indian manufacturing. Santosh Kumar Sahu. $\quad$ Retrieved from http://mpra.ub.unimuenchen.de/16606/1/Determinants_of_Energy_Intensity_A_Preliminary_Investigata_pdf

Dahan, A A. (1996). Economic analysis of energy consumption in Yemen. Ph.D. thesis, University of Arizona, USA.

Dahl, C. A. (1993a). A survey of energy demand elasticities in support of the development of the NEMS. In Dewees, D. N., Hyndman, R. M., \& Waverman, L. (Eds.), The demand for gasoline in Canada, 1956-1972 (pp. 116-123). Energy Policy.

Energy Information Administration (EIA). (2013). Retrieved from http://www.indexmundi.com/energy.aspx? country=ye\&product=gasoline\&graph=consumption

Factors Affecting Energy Intensity. (2013). Retrieved from http://www.rand.org/content/dam/rand/pubs/monograph_reports/MR1616/MR1616.ch3.pdf

Fisher, F. M., \& Kaysen, C. (1962). A study in econometrics: The demand for electricity in the United States. Amsterdam North Holand Publishing Company.

Greene, D. L. (1979). State differences in the demand for gasoline: An econometric a nalysis. Energy Systems and Policy, 3(2), 191-212.

Halvorsen, R. (1978). Econometric models of US. Energy Demand. Lexington Books. 
Harry, H., Kelejian, W., \& Oates, E. (1989). Introduction to econometrics principles and applications (3rd ed.). Harper \& Row.

Jyoti, K. P. (1981). Modeling energy demand for policy analysis. Ministry of Oil \& Mineral Resources, the Republic of Yemen.

Karen, F. V. (2004). What is driving China's decline in What is driving China's decline in energy intensity? Retrieved from http://www.researchgate.net/publication/222297802_What_is_driving_Chinas_decline_in_energy_intensity

Lee, C. C. (2005). Energy consumption and GDP in developing countries: A cointegrated panel analysis. Retrieved from http://eneken.ieej.or.jp/en/data/pdf/400.pdf

LISEa, W., \& Van Montfort, K. (2005). Energy consumption and GDP in Turkey: Is there a co - integration relationship? Retrieved from http:/www.ecn.nl/docs/library/report/2005/rx05191

Mehrara, M. (2007). Energy consumption and economic growth: The case of oil exporting countries. Energy Policy, 35(5). http://dx.doi.org/10.1016/j.enpol.2006.10.018

Ramachandra, T. V., Yves, L., \& Shruthi, B. V. (2006). Intra and inter country energy intensity trends. The Journal of Energy and Development, 31(1), 43-84.

Ramsy, J., Rasche, R., \& Allen, B. (1974). An analysis of private and commercial demand for gasoline. Review of Economics and Statistics, 502-507.

Robert, S. P. (1979). The structure of world energy demand.

Souhila, E. C., \& Baghdad, K. (2012). Energy consumption and economic growth in Algeria: Co integration and causality Analysis. International Journal of Energy Economics and Policy, 2(4), 238-249.

Statistical Review of Energy Report. (2010). Statistical yearbook, different issues. The Republic of Yemen.

The World Bank. (2002). Economic growth in the Republic of Yemen. Sources, Constraints, and Potentials, The World Bank, Sana'a.

The World Bank. (2004). The oil \& gas sector in the Republic of Yemen. World Bank Oil \& Gas Policy Division.

Wing, I. S., \& Eckaus, R. S. (2007). The decline in U.S. energy intensity: Its origins and implications for long-run CO2 emission projections. Retrieved from http://www.economics.mit.edu/files/2624

\section{Copyrights}

Copyright for this article is retained by the author(s), with first publication rights granted to the journal.

This is an open-access article distributed under the terms and conditions of the Creative Commons Attribution license (http://creativecommons.org/licenses/by/3.0/). 